\title{
RENDAHNYA KESANTUNAN BAHASA DI WILAYAH TANGERANG RAYA AKIBAT FAKTOR LINGKUNGAN
}

\author{
Ilhamudin \\ Universitas Pamulang \\ ilhamuddin.alsyari@gmail.com
}

\begin{abstract}
ABSTRAK
Rendahnya kesopanan bahasa diberbagai kalangan anak-anak, remaja, bahkan sampai orang dewasa. Anak-anak hanya bisa meniru cara berkomunikasi bahasa yang digunakan remaja dan orang dewasa kemudian diterapkan dalam kehidupan anak-anak dan temannya. Selaku orang tua merasa sedih melihat dan mendengarkan anak-anaknya berbahasa yang tidak sopan ketika berkomunikasi, akan tetapi orang tua tetap berusaha mendidik agar anaknya bisa berbahasa sopan dan santun dalam pergaulannya. Mengingat bangsa Indonesia memiliki bahasa yang penuh sopan dan santun maka dalam pergaulan dimana kita berada, kita harus tetap menjaga kualitas bahasa Indonesia agar eksistensi nilai bahasa yang berbudi pekerti tetap terjaga dengan baik. Karya tulis ini bertujuan untuk merumuskan beberapa konsep yang digunakan sebagai solusi atas menurunnya penggunaan kesopanan bahasa di kalangan masyarakat, khususnya masyarakat Tangerang Raya. Fokus pembahasan karya tulis ini adalah mewujudkan wilayah Tangerang Raya akan tingginya sopan santun dalam berbahasa dan masyarakat Tangerang Raya sebagai subjeknya. Gagasan ini ditulis dengan analisis dari beberapa permasalahan yang terjadi pada masyarakat Tangerang Raya di Indonesia, yang dikombinasi dengan solusi logis berdasarkan tinjauan pustaka atau studi literatur yang ada. Berdasarkan hasil analisis diketahui bahwa rendahnya penggunaan kesopanan bahasa di kalangan masyarakat dikarenakan beberapa faktor yakni anggapan bahwa bahasa sopan santun itu sulit, tidak bergengsi, dan tidak praktis. Sehingga, muncullah sebuah gagasan untuk mengefektifkan penggunaan bahasa sopan santun melalui perwujudan rendahnya kesopanan bahasa diwilayah Tangerang Raya. Dengan menerapkannya kesopanan bahasa dapat meningkatkan kualitas bahasa Indonesia didalam negeri maupun internasional dan eksistensi nilai bahasa yang berbudi pekerti dapat dijadikan sebagai contoh nyata bahwa bangsa Indonesia adalah bangsa yang besar akan kesantunan berbahasa dan menjadi sebuah harta karun dan kekayaan bangsa. Menjunjung tinggi bahasa Indonesia sudah selayaknya dilakukan dengan cara menggunakan bahasa Indonesia yang baik dan benar.
\end{abstract}

Kata kunci: kesantunan bahasa, mendidik, menjaga eksistensi

\section{PENDAHULUAN}

Setiap individu berasal dari latar belakang bahasa dan budaya yang berbeda sehingga sering dihadapkan pada miskomunikasi berbahasa. Hal ini dapat terjadi karena adanya perbedaan prinsip dan aturan pragmatis dari satu budaya ke budaya lainnya, (Gunduz, 2012, hlm. 52). Suatu bahasa tidak dapat dipisahkan dari budayanya. Ada beberapa aspek dari setiap bahasa yang terikat budaya dan membutuhkan pengetahuan bahasa yang memadai untuk mengungkapnya, Ekwelibe (2015, hlm.87). Setiap bahasa memiliki lingkungan budayanya sendiri, perubahan global, dan lokal dalam masyarakat yang menyebabkan perubahan dalam penggunaan kesopanan linguistik juga, Kumari (2015, hlm. 267).

Salah satu fenomena universal yang selalu kita jumpai dalam kehidupan bermasyarakat di ranah sosial adalah rendahnya kesopanan berbahasa yang digunakan oleh masyarakat khususnya diwilayah Tangerang Raya. Rendahnya kesopanan berbahasa dalam ranah kehidupan bermasyarakat merupakan salah satu fenomena penggunaan bahasa dalam konteks sosial yang menarik untuk dijadikan sebagai objek penelitian.

Konteks sosial selalu muncul dalam kegiatan berbahasa dikehidupan masyarakat Tangerang Raya. Banyaknya mayoritas masyarakat Tangerang Raya menggunakan bahasa Sunda dan bahasa Indonesia untuk berkomunikasi. Akan tetapi dikalangan anak-anak, remaja bahkan orang dewasa menggunakan bahasa gaul saat berkomunikasi. Padahal kita sebagai bagian bangsa Indonesia sudah selayaknya menjunjung tinggi bahasa Indonesia dalam kehidupan sehari-hari. Dewasa ini pemakaian bahasa Indonesia baik dalam kehidupan sehari-hari mulai bergeser digantikan dengan pemakaian bahasa anak remaja yang dikenal dengan 
bahasa gaul. Interferensi bahasa gaul kadang muncul dalam penggunaan bahasa Indonesia dalam situasi resmi yang mengakibatkan penggunaan bahasa tidak baik dan tidak benar.

Kesantunan berbahasa merupakan konsep yang dipandang sebagai realisasi perilaku sosial yang tepat yang dikembangkan oleh masyarakat untuk memfasilitasi interaksi antar manusia. Lakoff (1972, hlm. 298) mendefinisikan kesopanan berbahasa yaitu "Kesopanan tuturan itu dapat dicermati dari tiga hal, yakni dari sisi keformalannya, ketidaktegasannya, dan peringkat kesejajarannya atau kesekawanannya. Semakin tidak formal, semakin tidak tegas, semakin rendah peringkat kesejajarannya maka di pastikan tuturan itu akan memiliki gradasi kesantunan yang semakin rendah. Sebaliknya, semakin formal, semakin tegas, dan semakin tinggi jarak kesekawanannya, akan semakin tinggilah gradasi kesantunan itu."

Konsep kesantunan ini berkait erat dengan persoalan bagaimana cara seseorang dapat menghindari sebuah konflik. Dalam teorinya, kesantunan juga berkaitan dengan konsep muka. Kedua hal tersebut dinyatakan sebagai ciri-ciri universal yang dimiliki semua penutur dan petutur, (Brown \& Levinson, (1987, hlm. 74).

Bahasa mencerminkan bangsa. Demikian pameo yang sering kita dengar. Memang, tindak tutur seseorang tidak saja mencerminkan identittas geografis orang tersebut, tetapi juga mencerminkan kualitas orang tersebut. Orang yang berpendidikan, mestilah ia dapat menggunakan bahasa dengan baik, sesuai dengan konteks yang tepat, dan pemilihan kata dan kalimat yang tepat pula.

Tujuan dan manfaat yang ingin dicapai dalam karya tulis ini yaitu untuk menumbuhkembangkan kesopanan bahasa dalam pendidikan berkarakter, untuk mencegah terjadinya konflik atau perselisihan dan agar terciptanya hubungan yang harmonis. Kemudian memberikan pemahaman kepada masyarakat terhadapnya pentingnya menjaga kesopanan bahasa dalam berkomunikasi khususnya dikalangan anak-anak, remaja, dan dewasa untuk selalu menggunakan bahasa yang sopan dan santun sehingga menciptakan kerukunan antar sesama pengguna bahasa.

\section{METODE PENELITIAN}

Metode pelaksanaan artikel ini menggunakan penelitian kualitatif dan kuantitatif, yaitu bersosialisasi dengan orang tua anak anak agar dapat mendidik pendidikan berkarakter dan membimbing anaknya dalam pergaulan diluar yang dapat membawa anaknya dalam bahasa yang tidak baik dan tidak benar. Mengajak kepada teman sebaya dan orang dewasa agar lebih sopan dan santun dalam berbahasa agar anak-anak, adikadik, dan penerus bangsa kita dapat memiliki kepribadian yang baik dan benar dalam berkomunikasi.

\section{HASIL PEMBAHASAN}

Saat ini masih banyak yang terjadi diwilayah Tangerang Raya khususnya, berbahasa dengan menggunakan bahasa kasar atau disebut bahasa gaul. Kejadian yang pernah di alami sendiri ketika sedang berkumpul dengan teman sebaya alumie SMA, awal mula berkomunikasi masih menggunakan bahasa Indonesia yang baik dan benar, akan tetapi setelah beberapa menit kemudian interferensi bahasa gaulpun muncul mengakibatkan penggunaan bahasanya tidak enak untuk didengar dan dapat mencerminkan kepribadian yang buruk dimata orang yang mendengarkannya.

Suatu kejadian juga yang pernah dijumpai disuatu tempat ada orang dewasa sedang berkumpul dengan teman-temannya dan beberapa anak-anak dengan teman-temannya juga. Ketika orang dewasa berkomunikasi dengan temannya menggunakan bahasa gaul dan terdengar oleh beberapa anak-anak yang sedang berkumpul, keesokan harinya anak-anak tersebut mengikuti bahasa yang digunakan orang dewasa yaitu bahasa gaul.

\section{Upaya Yang Dilakukan Beserta Hasilnya}

Bersosialisasi dengan orang tua anak-anak agar dapat mendidik pendidikan berkarakter dan membimbing anaknya dalam pergaulan diluar yang dapat membawa anaknya dalam bahasa yang tidak baik dan tidak benar. Mengajak kepada teman sebaya dan orang dewasa agar lebih sopan dan santun dalam berbahasa agar anak-anak, adik-adik, dan penerus bangsa kita dapat memiliki kepribadian yang baik dan benar dalam berkomunikasi.

Mengingat bangsa Indonesia memiliki bahasa yang penuh sopan dan santun maka dalam pergaulan dimana kita berada, kita harus tetap menjaga kualitas bahasa Indonesia agar eksistensi nilai bahasa yang berbudi pekerti tetap terjaga dengan baik. 
Dalam hasil survei diruang terbuka alhamdulillah hari demi hari sudah terlihat perkembangan berbahasa ketika berkomunikasi. Awal mula orang dewasa memulai dengan bahasa yang baik, sopan dan santun maka anak-anak mengikutinya dengan bahasa yang baik, sopan dan santun.

Untuk masyarakat tidak akan pernah merasa gelisah dan mendengar bahasa yang kotor atau tidak enak didengar ketika ada perkumpulan anak-anak, remaja, bahkan orang dewasa dalam berkomunikasi. Dengan bahasa sopan dan santun kita akan selalu terjaga keharmonisan dan dijauhi dari terjadinya konflik.

Gagasan ini akan terwujud apabila adanya dukungan dari kesadaran masyarakat, anak-anak, remaja, orang dewasa betapa pentingnya kesopanan bahasa dalam berkomunikasi dilingkungan sekitar. Dan adanya dukungan dari pemerintah daerah maupun pemerintah pusat dalam membuat suatu standardisasi atau kebijakan untuk menghimbau serta mengajak kepada semua golongan atas dan bawah agar bisa menerapkan bahasa sopan dan santun ketika berkomunikasi.

Tabel Peranan Elemen Terkait Dalam Pengembangan Kesopanan Bahasa

\begin{tabular}{|c|l|l|}
\hline No. & \multicolumn{1}{|c|}{ Pihak-Pihak } & \multicolumn{1}{c|}{ Peranan } \\
\hline 1 & $\begin{array}{l}\text { Kementerian Pendidikan } \\
\text { dan Kebudayaan }\end{array}$ & $\begin{array}{l}\text { Pelindung, penyusun kebijakan teknis, } \\
\text { rencana dan program pengembangan } \\
\text { kesopanan bahasa }\end{array}$ \\
\hline 2 & $\begin{array}{l}\text { Pemerintah Tangerang } \\
\text { Raya }\end{array}$ & $\begin{array}{l}\text { Pemantau dan pengevaluasi pelaksanaan } \\
\text { pengembangan kesopanan bahasa }\end{array}$ \\
\hline 3 & $\begin{array}{l}\text { Masyarakat Tangerang } \\
\text { Raya }\end{array}$ & $\begin{array}{l}\text { Memberikan arahan yang baik dan benar } \\
\text { cara berkomunikasi dengan bahasa sopan } \\
\text { dan santun }\end{array}$ \\
\hline 4 & Orang Dewasa & $\begin{array}{l}\text { Mengajak dan memberikan contoh } \\
\text { berkomunikasi dengan bahasa sopan santun }\end{array}$ \\
\hline
\end{tabular}

Bagan Teknik Implementasi Kesantunan Bahasa Di Tangerang Raya

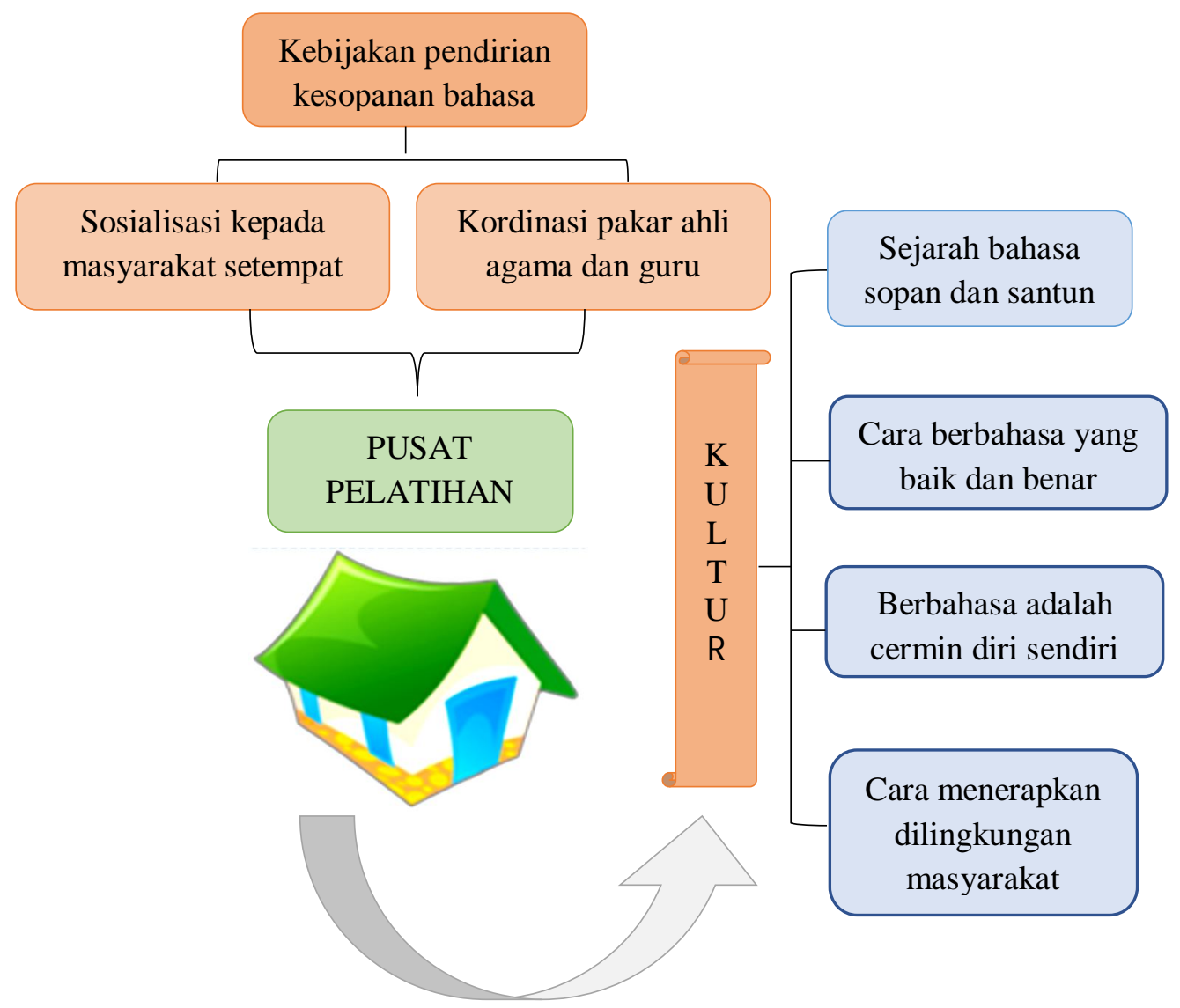




\section{SIMPULAN}

Dengan menerapkannya kesopanan bahasa dapat meningkatkan kualitas bahasa Indonesia didalam negeri maupun internasional dan eksistensi nilai bahasa yang berbudi pekerti dapat dijadikan sebagai contoh nyata bahwa bangsa Indonesia adalah bangsa yang besar akan kesantunan berbahasa dan menjadi sebuah harta karun dan kekayaan bangsa. Menjunjung tinggi bahasa Indonesia sudah selayaknya dilakukan dengan cara menggunakan bahasa Indonesia yang baik dan benar.

Kesopanan berbahasa merupakan salah satu aspek kebahasaan yang dapat meningkatkan kecerdasan emosional penuturnya karena didalam komunikasi, penutur dan petutur tidak hanya dituntut menyampaikan kebenaran, tetapi harus tetap berkomitmen untuk menjaga keharmonisan hubungan.

Keharmonisan hubungan penutur dan petutur tetap terjaga apabila masing- masing peserta tutur senantiasa tidak saling mempermalukan. Pentingnya kesantunan dalam bertutur yaitu dapat menciptakan komunikasi yang efektif antara penutur dan mitra tutur.

Karena kesopanan sebagai perilaku yang diekspresikan dengan cara yang baik atau beretika dan merupakan fenomena kultural, sehingga apa yang dianggap santun oleh suatu kultur mungkin tidak demikian halnya dengan kultur yang lain. Artinya kesantunan merupakan aspek kebahasaan yang amat penting karena dapat memperlancar interaksi antar individu.

\section{DAFTAR PUSTAKA}

Anwar, Qomari. 2010. Agama Nilai Utama dalam Membangun Karakter Bangsa. pendikar.dikti.go.id/gdp/wp-content/uploads/karakter-SIAP.pdf, diakses 11 Februari 2021.

Hidayatullah, M. Furqon. 2010. Pendidikan Karakter: Membangun Peradapan Bangsa. Surakarta: Yuma Pustaka.

Kemendiknas. 2010. Pengembangan pendidikan budaya dan karakter bangsa (Pedoman sekolah). Jakarta:

Kementerian Pendidikan Nasional, Badan Penelitian dan Pengembangan Pusat Kurikulum.

Pujiati, Tri. (2021). Kesantunan Berbahasa Dalam Pelayanan Kesehatan. Depok: CV. Pena Persada.

Ramadhan, Rizkasyah. (2017). Implementasi Norma Kesopanan, http://eprints.ums.ac.id/61385/11/Artikel\%20Publikasi.pdf, diakses 11 Februari 2021.

Rohali. (2011). Kesantunan Bahasa Sebagai Pilar Pendidikan Karakter, https://journal.uny.ac.id/index.php/jpka/article/viewFile/1444/1233, diakses 13 Februari 2021. 